\title{
Substrates and Sowing Depths in the Production of Pansy Seedlings (Viola tricolor L.)
}

\author{
B. B. Reis ${ }^{1}$, D. B. Rodrigues ${ }^{1}$, A. S. Almeida ${ }^{1}$, H. L. Chagas ${ }^{1}$, A. S. Suné ${ }^{1}$, E. Geweher ${ }^{1}$, C. A. Nunes ${ }^{1}$, \\ A. A. O. Peres ${ }^{1}$, L. Konzen ${ }^{1}$, G. F. Rodrigues ${ }^{1}$, A. M. Assis ${ }^{1} \&$ L. V. M. Tunes ${ }^{1}$ \\ ${ }^{1}$ University of Pelotas, Pelotas, Brazil \\ Correspondence: B. B. Reis, University of Pelotas, Pelotas, Brazil. E-mail: brunabarretoreis-@hotmail.com
}

Received: July 25, 2018

doi:10.5539/jas.v11n16p159
Accepted: June 30, 2019 Online Published: September 30, 2019

URL: https://doi.org/10.5539/jas.v11n16p159

\begin{abstract}
The success of seedling production for ornamental or any other crops depends on several factors, including the use of highquality seeds and the choice of suitable substrates. The aim of this work was to evaluate the use of different organic residues as substrates and sowing depths on the emergence and initial development of pansy seedlings. Two lots of pansy seeds were used. Seed lot quality was evaluated for water content determination, 1000 -seeds weight, germination, first count of germination, accelerated aging, seedling emergence in sand. Post emergence was evaluated by the emergence speed index, shoot length, shoot dry matter and number of leaves. The experiment was performed under completely randomized design, with four replicates. Data were submitted to analysis of variance through the F-test and the means, compared to each other by the Tukey test, at $5 \%$ probability. The most indicated sowing depths for the development of pansy seedlings were 1.5 and $2 \mathrm{~cm}$ while the substrate which presented the best results was the Beifort ${ }^{\circledR}$ S10.
\end{abstract}

Keywords: carbonized rice husk, coconut coir, emergence, ornamental plants

\section{Introduction}

In Brazil, the production of flowers and ornamental plants is a growing economic activity, wherein the climatic diversity of the territory enables the cultivation of native and exotic species from tropical to temperate climates (Junqueira \& Peetz, 2017). Between the exotic flowers currently produced is the pansy (Viola tricolor L.). This species belongs to the Violaceae family and is originated in Europe, presenting an annual cycle and an erect growth, whith a short and branched stem, reaching a maximum of thirty centimeters in height while flowers vary from five to thirteen centimeters in diameter. The pansy is usually used in landscaping, as coverage and sorrounding flowerbeds and has also been widely used in cooking and phytotherapy due to anti-inflammatory properties (Fernandes, Leal, \& Moraes, 2015).

The success of pansy propagation depends on several factors, which include the use of suitable substrates and high-quality seeds. These factors are directly related to seedling emergence and the production of good quality seedlings (Nicoloso, Fortunato, Zanchetti, Cassol, \& Eisinger, 2000). According to Araújo Neto, Azevedo, Galvão, Oliveira, and Ferreira (2009), the substrate influences the maintenance of the root system of the plant, through the solid phase and is responsible for the availability of water and nutrients to the plants by the liquid phase, acting directly on seed germination and the development and architecture of the root system and shoot formation. The substrates must have physical and chemical properties, such as water holding capacity, porosity, structural stability, besides being free of pathogens, pests, seeds of invasive species and harmful substances which can hinder plant development (Kämpf, 2005).

Peat is the main component of most commercial substrates, however, growing concern about environmental impacts associated with its extraction (Bullock, Collier, \& Convery, 2012) increased the efforts for total or partial replacement of this material for alternative low-cost materials (Ceglie, Bustamante, Amara, \& Tittarelli, 2015). Several studies concluded that the carbonized rice husk can be used as a sole or partial substrate for plant cultivation, for example, this material has been suscesfully used in the production of potted chrysanthemum (Terra et al., 2011). Furthermore, coconut coir has also been increasingly used as an alternative to peat (Xiong, Tian, Wang, Liu, \& Chen, 2017) and resulted in greater shoot and root dry mass during the acclimatization of Heliconia chartacea cv. Sexy Pink, a tropical cut flower native to Brazil (Quisen, Raizer, \& Iriarte-Martel, 2013). 
The identification of high-quality seed lots often utilizes vigor tests such as the first count of germination, the accelerated aging test, dry matter translocation tests, seedling emergence, emergence speed index, among others, which infer the ability of the seeds to produce healthy seedlings under limiting environmental conditions. The performance of seeds on these tests varies depending on the degree of severity applied. In soybeans, high vigor seeds resulted in greater plant emergence, shoot and root dry mass, height and stem diameter (Caverzan et al., 2018). Therefore, methods commonly used to evaluate seed quality through the analysis of seedling emergence and seedling performance can be also applied to identify the most suitable substrate, however, the results of these analizes will be affected by seed quality and sowing depth.

The ideal sowing depth is the one that guarantees rapid and homogeneous seed germination, rapid seedling emergence and production (Alves et al., 2008). Excessive sowing depths may impair seedling emergence, on the other hand, reduced depths predispose seeds to environmental variations such as hidryc excesses or deficits and temperature variations which can compromise the quality of the seedlings (Tillmann, Piana, Cavariani, \& Minami, 1994).

Due to these aspects, the work had the aim of evaluatinge the use of organic residues and sowing depth in the emergence and initial development of pansy seedlings.

\section{Method}

The work was carried out at the Federal University of Pelotas (UFPel) from January to December 2014. Pansy seeds represented by two lots from Beifuir (Garibaldi-RS) were used. The work was carried out in two stages: Seed lot characterization and Emergence and initial development of pansy seedlings.

\subsection{Seed Lot Characterization}

The first step of the work was conducted in the Seed Analysis Laboratory of the Phytotechny Department of the College of Agronomy "Eliseu Maciel" (FAEM-UFPel), the following procedures and tests were carried out for both seed lots:

1000-seeds weight: determined using eight subsamples of 100 seeds from the pure seed portion of each lot. The seeds were manually counted and then weighed in a precision balance with an accuracy of $0.0001 \mathrm{~g}$ (Brazil, 2009). The results were expressed in grams.

Germination: performed using twelve replications of 25 seeds per lot. The seeds were placed into gemination boxes (gerbox) and, as substrate, blotter paper moistened with distilled water in the ratio of 2.5 times the weight of the dry paper was used, under alternating temperatures of 20 to $30^{\circ} \mathrm{C}$. The evaluations were performed on the fourth, seventh and twenty-first day after sowing, according to criteria established by the Rules of Seed Analysis (Brazil, 2009). The results were expressed as percentage of normal seedlings for each seed lot.

First count of germination: carried out alongside the standard germination test, counting the number of normal seedlings on the seventh day after sowing. The results were expressed as percentage of normal seedlings.

Accelerated aging: performed on plastic boxes $(11.0 \times 11.0 \times 3.5 \mathrm{~cm})$ with an aluminum screen suspended in the upper portion. The seeds were homogenously deposited on a voile fabric placed above this screen. Each plastic box received $40 \mathrm{~mL}$ of distilled water. The capped boxes were maintained in BOD for $48 \mathrm{~h}$ at $41^{\circ} \mathrm{C}$. At the end of each period, the seeds were submitted to the germination test. The evaluations were carried out seven days after sowing and the results expressed as the percentage of normal seedlings for each seed lot.

Seedling emergence in sand: conducted in germination boxes, using 300 seeds for each lot distributed on 12 replicates of 25 seeds each. Each replicate was manually sown in 5 lines with 5 seeds. The boxes were maintained at a controlled temperature of $25^{\circ} \mathrm{C}$. Irrigation was performed as needed. Normal seedlings were counted at 21 days after sowing, when the number of emerged stabilized. The results were expressed as the percentage of normal seedlings, for each lot.

\subsection{Emergence and Initial Development of Pansy Seedlings}

The second step was performed in a plant propagation greenhouse at the Phytotechny Department at the College of Agronomy "Eliseu Maciel" (FAEM-UFPel). Four replicates of 25 seeds per lot were manually seeded in polyethylene trays with dimensions of $53.2 \mathrm{~cm}$ (Length) $\times 37.3 \mathrm{~cm}$ (Width) $\times 8.6 \mathrm{~cm}$ (Height), using two trays for each substrate. Five depths $\left(0 ; 0.5 ; 1.0 ; 1.5\right.$; and $2.0 \mathrm{~cm}$ ) and 3 types of substrates (Beifort ${ }^{\circledR} \mathrm{S} 10,47$ Amafibra ${ }^{\circledR}$ coconut coir and carbonized rice husk) were evaluated.

The carbonized rice husk was obtained from in natura rice husk, which was burned for 4 hours in an appropriate perforated barrel. Subsequently, the substrate was placed into a metal basin and moistened to cool down and no longer burn, which would result in rice husk ash. This substrate differs from the charred rice bark because of the 
granulometry and burning time. The coconut coir (Amafibra ${ }^{\circledR} 47$ Golden Mix) was purchased on the local market and moistened 48 hours prior to the installation of the experiment. The commercial substrate S10 Beifort ${ }^{\circledR}$, composed of agroindustrial organic waste (seed, grape marc, peat, carbonized rice husk and rice husk ash), was also purchased locally.

After sowing, trays were placed in the greenhouse, with a temperature and average air relative humidity of 20.91 ${ }^{\circ} \mathrm{C}$ and $62.35 \%$, respectively, which was recorded daily, at the same time, on a thermo hygrometer. Irrigation was performed daily using a spraying bottle with $600 \mathrm{ml}$ of water.

The following evaluations were carried out:

Seedling emergence: evaluated at 56 days after sowing, wherein plants with $0.5 \mathrm{~cm}$ or more in height were considered normal seedlings. The results were expressed as percentage of seedlings emerged for each lot, depth and substrate. The seedlings were then harvested in the trays.

Emergence speed index (ESI): carried out alongside the emergency test. The number of seedlings emerged daily was recorded from the day the first seedling was observed on the surface of the substrate. The evaluations were performed until complete stabilization, and the emergency speed index was calculated using the formula proposed by Maguire (1962): IVE: $(\mathrm{E} 1 / \mathrm{N} 1)+(\mathrm{E} 2 / \mathrm{N} 2)+\ldots+(\mathrm{En} / \mathrm{Nn})$, where: IVE = emergency speed index; E1, $\mathrm{E} 2, \ldots \mathrm{En}=$ number of normal seedlings recorded in each count; $\mathrm{N} 1, \mathrm{~N} 2, \ldots \mathrm{Nn}=$ number of days between sowing and each count. The results were expressed as the average emergence speed index for each lot, substrate and depth.

Shoot length: performed with 10 randomly selected normal seedlings for experimental unit, obtained from the seedling emergence test. The shoot length was measured with the aid of a graduated ruler and the results were presented in millimeters.

Shoot dry matter: The 10 seedlings were then placed in bags of Kraft paper and taken to the oven set at $60^{\circ} \mathrm{C}$ until reaching weight (48 hours) and, after that period, weighed in an analytical balance with precision of $0.001 \mathrm{~g}$.

\subsection{Statistical Analysis}

The experiment was performed under completely randomized design, with four replications. Data were submitted to analysis of variance through the $\mathrm{F}$ test and the means of the treatments were compared to each other by the Tukey test, at the $5 \%$ probability level.

\section{Results and Discussion}

The evaluations of first count of germination, germination, accelerated aging, seedling emrgence in sand and 1000 -seeds weight were performed only to characterize the physiological quality of the lots of pansy seeds. Therefore, statistical analyzes of these evaluations were not performed and the results are presented on Table 1 .

Table 1. Physiological quality characterization of pansy (Viola tricolor L.) seed lots. Pelotas-RS, 2015

\begin{tabular}{llllll}
\hline Lot & FCG (\%) & G (\%) & AA (\%) & SES (\%) & SW (g) \\
\hline Lot 1 & 30 & 80 & 12 & 70 & 0.079 \\
Lot 2 & 48 & 88 & 19 & 78 & 0.169 \\
\hline
\end{tabular}

Note. $\mathrm{FCG}=$ First Count of Germination; $\mathrm{G}=$ Germination; $\mathrm{AA}=$ Accelerated Aging; SES $=$ Seedling Emergence in Sand; SW $=1000$-seeds weight.

Observing the results of the tests performed to characterize the lots, the 1000 -seeds weight can be highlighted for lot 2 that presented more than twice the value observed for lot 1 . Seed size is an important characteristic for seeds, because of its relationship with physiological potential, which has been a contradictory subject in the studies performed by several researchers. According to Pádua, Zito, Arantes, and Neto (2010), seeds with higher density are potentially more vigorous due to well-formed embryos and higher reserve content. Antunes, Picolotto, Vignolo, and Gonçalves (2012) observed that, within a same seed lot, those seeds considered small present lower values for seedling emergence and vigor than thise seeds considered medium and large, therefore, seed size evaluates morphological aspects possibly associated with vigor.

The physical and chemical properties of the substrates are described in Table 2. The water holding capacity is particularly important for crop management, since this variable helps to determine the amount of water to be used for irrigation (Kämpf, De Siqueira, \& Takane, 2006). In this study, a greater water retention was observed for the coconut coir, followed by the carbonized rice husk and $\mathrm{S}-10$ Beifort $^{\mathbb{R}}$. The $\mathrm{pH}$ values are also important, 
because the activity of hydrogen ions interferes root and microorganism growth. When using organic substrates, without the addition of soil, Kämpf (2005) recommends that the $\mathrm{pH}$ should be in the range of 5.2 to 5.5. In the present study, it was observed that no substrate was within the recommended range. The electrical conductivity (EC) indicates the total soluble salt content (TSSC) and the concentration of ions in the substrate. The appropriate value, which is the degree of sensitivity to this attribute varies according to each species. According to Kämpf et al. (2006), high EC values $\left(6.6\right.$ to $7.8 \mathrm{dSm}^{-1}$ ) may cause water loss at the roots and the staining or burning of leaf edges. On the other hand, low EC values can lead to nutritional deficit and reduced plant growth.

Table 2. Physical and chemical characteristics of the substrates used in the emergence and early development of (Viola tricolor L.) plants. Pelotas RS, 2015

\begin{tabular}{|c|c|c|c|c|}
\hline Substrate & Density (g/L) & Water holding capacity $(\mathrm{mL} / \mathrm{L})$ & $\mathrm{pH}$ & Electrical conductivity $\left(\mu \mathrm{S} \mathrm{cm}^{-1}\right)$ \\
\hline Coconut coir & 163.12 & 624.00 & 5.70 & 633.6 \\
\hline Carbonized rice husk & 206.00 & 621.50 & 6.69 & 624.1 \\
\hline S-10 Beifort ${ }^{\circledR}$ & 456.51 & 493.00 & 6.42 & 692.0 \\
\hline
\end{tabular}

In the present work, the highest $\mathrm{EC}$ value was verified in $\mathrm{S}-10 \mathrm{Beifort}{ }^{\circledR}$, which can be justified by the materials used in this substrate, with higher nutrient contents and colloidal characteristics, that favor cation adsorption and may have raised the EC of the substrate. Furthermore, commercial substrates usually have some fertilizer added in the mixture. These results contrast those found by Assis et al. (2011), which observed greater averages for coffee bark mixtures with coconut coir and carbonized rice husk in orchid cultivation.

Table 3 presents the results of the emergence speed index. There was no interaction between the substrate and sowing depth. For lot 1 , the depth of $0 \mathrm{~cm}$ was the one that showed the best results, while not statistically differing from 1.0 and $1.5 \mathrm{~cm}$. The lowest mean was observed for the depth of $2 \mathrm{~cm}$. For lot 2, the effect of the sowing depths tested in this study was not significant. Probably, with the increasing depth, the seedlings consumed more energy during the germination process, which resulted in a slower and more uneven emergence for lot 1. Similarly, for seeds of Bauhinia divaricata L., Freire, Alves, Santos, Porcino, and Silva (2014) observed that there was a decrease in the speed of emergence as the depth increased. For the substrates, the best results were observed for S-10Beifort ${ }^{\circledR}$ and the carbonized rice husk. These results are consistent with the results obtained by Silva et al. (2002), who concluded that the substrates formed from vermicompost mixtures plus rice husk in the ratios (2:1) and (3:1) presented better results for the rate of emergence, percentage of germination and plant development.

Table 3. Emergence speed index of two lots of pansy (Viola tricolor L.) seeds subjected to different substrates and sowing depths. Pelotas, RS, 2015

\begin{tabular}{|c|c|c|c|c|c|}
\hline & \multicolumn{5}{|c|}{ Emergence speed index } \\
\hline & \multirow{2}{*}{ Depth $(\mathrm{cm})$} & \multicolumn{3}{|c|}{ Substrate } & \multirow{2}{*}{ Average } \\
\hline & & S-10Beifort $^{(R)}$ & $\mathrm{CRH}$ & $\mathrm{CC}$ & \\
\hline \multirow{7}{*}{ Lot 1} & 0 & 0.51 & 0.68 & 0.45 & $0.55 \mathrm{~A}^{*}$ \\
\hline & 0.5 & 0.38 & 0.28 & 0.13 & $0.26 \mathrm{~B}$ \\
\hline & 1.0 & 0.50 & 0.45 & 0.25 & $0.40 \mathrm{AB}$ \\
\hline & 1.5 & 0.38 & 0.48 & 0.29 & $0.38 \mathrm{AB}$ \\
\hline & 2.0 & 0.54 & 0.20 & 0.26 & $0.33 \mathrm{~B}$ \\
\hline & Average & $0.46 \mathrm{a}^{*}$ & $0.42 \mathrm{a}$ & $0.28 \mathrm{~b}$ & \\
\hline & C.V. $(\%)$ & 37.29 & & & \\
\hline \multirow{7}{*}{ Lot 2} & 0 & 0.99 & 1.05 & 0.74 & 0.93 \\
\hline & 0.5 & 1.32 & 0.96 & 0.98 & 1.09 \\
\hline & 1.0 & 1.21 & 1.15 & 0.73 & 1.03 \\
\hline & 1.5 & 1.11 & 0.81 & 0.99 & 0.97 \\
\hline & 2.0 & 0.97 & 0.82 & 0.83 & 0.87 \\
\hline & Average & $1.12 \mathrm{a}^{*}$ & $0.96 \mathrm{ab}$ & $0.85 b$ & \\
\hline & C.V. $(\%)$ & 25.68 & & & \\
\hline
\end{tabular}

Note. $\overline{\mathrm{CRH}}=$ carbonized rice husk; $\mathrm{CC}=$ coconut coir; $*$ Means followed by the same uppercase letter in the column and lowercase in the line do not differ from each other by the Tukey Test, at the $5 \%$ error probability level. 
The sowing depth significantly affected shoot length for lot 1 (Table 4). The depth of $1.5 \mathrm{~cm}$ presented the greater average, however, not statistically different from the depths of $0.5,1$, and $2 \mathrm{~cm}$. Similar results were found by Freire et al. (2014), in an experiment with seeds of Bauhinia divaricata L. Alves et al. (2014) stated that sowing should not be performed at excessive depths due to the weight of the substrate layer which creates a physical barrier for seedling emergence, especially the less vigorous, these authors also reported that more superficial seedings are more susceptible to environmental variations, which might lead to small and weak seedlings. For lot 2 , there was interaction between substrates and sowing depths, the substrates S-10Beifort ${ }^{\circledR}$, coconut coir, and carbonized rice husk were positively affected by the increase in sowing depth. For $\mathrm{S}-10$ Beifort ${ }^{\circledR}$ the depths of $1.0,1.5$ and $2 \mathrm{~cm}$ presented the greater averages, which were significantly different from 0 and $0.5 \mathrm{~cm}$. For coconut coir the depth of $1.5 \mathrm{~cm}$ presented the greater average which was not different from the depths of 1.0 and 2.0. For the carbonized rice husk there was no difference between the depths examined in this study. Monquero, Hijano, Orzari, Sabbag, and Hirata (2012) observed greater emergence of Rottboellia exaltata (L.) at a sowing depth $5.0 \mathrm{~cm}$. On the other hand, Lone, Barbosa, Takahashi, and Faria (2008), studying different substrates in the acclimatization of Cattleya (Orchidaceae), verified that the carbonized rice bark showed inferior performance to the coconut coir for the variable shoot length.

Table 4. Shoot length of two lots of pansy (Viola tricolor L.) seeds subjected to different substrates and sowing depths. Pelotas, RS, 2015

\begin{tabular}{|c|c|c|c|c|c|}
\hline & \multicolumn{5}{|c|}{ Shoot length (mm) } \\
\hline & \multirow{2}{*}{ Depth $(\mathrm{cm})$} & \multicolumn{3}{|c|}{ Substrate } & \multirow{2}{*}{ Average } \\
\hline & & S-10Beifort ${ }^{(B)}$ & $\mathrm{CRH}$ & $\mathrm{CC}$ & \\
\hline \multirow{7}{*}{ Lot 1} & 0 & 10.13 & 10.00 & 11.02 & $10.38 \mathrm{~B}^{*}$ \\
\hline & 0.5 & 10.80 & 11.48 & 12.75 & $11.68 \mathrm{AB}$ \\
\hline & 1.0 & 11.05 & 10.33 & 10.75 & $10.71 \mathrm{AB}$ \\
\hline & 1.5 & 13.30 & 14.00 & 14.25 & $13.85 \mathrm{~A}$ \\
\hline & 2.0 & 15.40 & 11.25 & 14.87 & $13.84 \mathrm{AB}$ \\
\hline & Average & 12.14 & 11.41 & 12.73 & \\
\hline & C.V. $(\%)$ & 24.61 & & & \\
\hline \multirow{7}{*}{ Lot 2} & 0 & $11.00 \mathrm{Ba}^{*}$ & $6.95 \mathrm{Ac}$ & $8.65 \mathrm{Cb}$ & 8.87 \\
\hline & 0.5 & $12.75 \mathrm{Ba}$ & $7.45 \mathrm{Ac}$ & $9.52 \mathrm{BCb}$ & 9.91 \\
\hline & 1.0 & $14.35 \mathrm{Aa}$ & 7.97Ac & $11.87 \mathrm{Ab}$ & 11.40 \\
\hline & 1.5 & $13.70 \mathrm{Aa}$ & $7.15 \mathrm{Ab}$ & $12.45 \mathrm{Aa}$ & 11.10 \\
\hline & 2.0 & $14.10 \mathrm{Aa}$ & $7.95 \mathrm{Ab}$ & $11.15 \mathrm{ABb}$ & 11.07 \\
\hline & Average & 13.18 & 7.49 & 10.73 & \\
\hline & C.V. $(\%)$ & 28.71 & & & \\
\hline
\end{tabular}

Note. $\overline{\mathrm{CRH}}=$ carbonized rice husk; $\mathrm{CC}=$ coconut coir; $*$ Means followed by the same uppercase letter in the column and lowercase in the line do not differ from each other by the Tukey Test, at the $5 \%$ error probability level.

The variable number of leaves only showed significant differences between the substrates (Table 5). The substrate S-10Beifort ${ }^{\circledR}$ demonstrated the best performance for this variable for the two seed lots tested. The results obtained by Lone et al. (2010) showed significant results for the number of leaves in the substrate coconut coir and carbonized rice bark in Rhododendron simsii Planch. Some physical characteristics, such as density and water retention capacity of the S-10Beifort ${ }^{\circledR}$ substrate (Table 2) might have favored the development of pansy seedlings. According to Nomura, Fuzitani, Valéria, Junior, \& Mariotto et al., (2011), seedlings with greater number of leaves have higher survival indexes at transplant, due to a greater capture of solar energy and higher organic matter production via photosynthesis. 
Table 5. Number of leaves per plant of two lots of pansy (Viola tricolor L.) seeds subjected to different substrates and sowing depths. Pelotas, RS, 2015

\begin{tabular}{|c|c|c|c|c|c|}
\hline & \multicolumn{5}{|c|}{ Number of leaves per plant } \\
\hline & \multirow{2}{*}{ Depth $(\mathrm{cm})$} & \multicolumn{3}{|c|}{ Substrate } & \multirow{2}{*}{ Average } \\
\hline & & S-10Beifort ${ }^{(R)}$ & $\mathrm{CRH}$ & $\mathrm{CC}$ & \\
\hline \multirow{7}{*}{ Lot 1} & 0 & 7 & 4 & 4 & 5 \\
\hline & 0.5 & 7 & 4 & 5 & 5 \\
\hline & 1.0 & 7 & 4 & 5 & 5 \\
\hline & 1.5 & 8 & 5 & 6 & 6 \\
\hline & 2.0 & 7 & 4 & 5 & 5 \\
\hline & Average & $7 a^{*}$ & $4 \mathrm{~b}$ & $5 c$ & \\
\hline & C.V. $(\%)$ & 19.36 & & & \\
\hline \multirow{7}{*}{ Lot 2} & 0 & 7 & 4 & 5 & 5 \\
\hline & 0.5 & 7 & 5 & 5 & 6 \\
\hline & 1.0 & 7 & 5 & 5 & 6 \\
\hline & 1.5 & 7 & 4 & 6 & 6 \\
\hline & 2.0 & 7 & 5 & 5 & 6 \\
\hline & Average & $7 \mathrm{a}^{*}$ & $5 \mathrm{~b}$ & $5 \mathrm{c}$ & \\
\hline & C.V. $(\%)$ & 13.05 & & & \\
\hline
\end{tabular}

Note. $\mathrm{CRH}=$ carbonized rice husk; $\mathrm{CC}=$ coconut coir; *Means followed by the same uppercase letter in the column and lowercase in the line do not differ from each other by the Tukey Test, at the 5\% error probability level.

The variable shoot dry matter (Table 6) only showed significant differences for lot 1 for the factor sowing depth where the depths 1.5 and $2.0 \mathrm{~cm}$ were superior to the others. For the lot 2, the interaction between the factor substrate and sowing depth was observed. The substrate $\mathrm{S}-10 \mathrm{Beifort} \AA$ the depths of 1.5 and $2 \mathrm{~cm}$ presented the greater averages, but did not differ statistically from $0 \mathrm{~cm}$. For the carbonized rice husk there was no effect of the depths studied. For the coconut coir the highest average was observed for depth of $0.5 \mathrm{~cm}$, which did not differ from 1.0, $1.5 \mathrm{~cm}$ and 2.0. According to Sousa, Ribeiro, Mende, Maracajá, and Costa (2007), the adequate sowing depth is peculiar to each species and, when appropriate, provides uniformity of germination and seedling emergence. For Cardoso, Alves, Bruno, Alves, and Silva (2008) it is considered an ideal seeding depth that guarantees homogeneous germination of seeds and rapid emergence of seedlings, thus producing vigorous seedlings. The results obtained in the present work are in accordance with those verified by Sousa et al. (2007) which recommended the depth of $2.0 \mathrm{~cm}$. Alves et al. (2008) observed a reduction in the dry matter mass of the juazeiro (Zizyphus joazeiro Mart.) seedlings at each centimeter increase in sowing depth. 
Table 6. Shoot dry matter of two lots of pansy (Viola tricolor L.) seeds subjected to different substrates and sowing depths. Pelotas, RS, 2015

\begin{tabular}{|c|c|c|c|c|c|}
\hline & \multicolumn{5}{|c|}{ Shoot dry matter (mg) } \\
\hline & \multirow{2}{*}{ Depth $(\mathrm{cm})$} & \multicolumn{3}{|c|}{ Substrate } & \multirow{2}{*}{ Average } \\
\hline & & S-10Beifort ${ }^{(B)}$ & $\mathrm{CRH}$ & $\mathrm{CC}$ & \\
\hline \multirow{7}{*}{ Lot 1} & 0 & 1.31 & 2.09 & 1.29 & $1.56 \mathrm{~B}^{*}$ \\
\hline & 0.5 & 1.23 & 1.51 & 2.19 & $1.64 \mathrm{~B}$ \\
\hline & 1.0 & 1.43 & 2.61 & 2.04 & $2.03 \mathrm{~B}$ \\
\hline & 1.5 & 2.25 & 3.06 & 3.40 & $2.90 \mathrm{~A}$ \\
\hline & 2.0 & 186 & 3.18 & 3.39 & $2.81 \mathrm{~A}$ \\
\hline & Average & $1.62^{-}$ & 2.49 & 2.46 & \\
\hline & C.V. $(\%)$ & 29.56 & & & \\
\hline \multirow{7}{*}{ Lot 2} & 0 & $2.38 \mathrm{Ab}^{*}$ & $2.05 \mathrm{Ab}$ & $2.95 \mathrm{Bb}$ & 2.46 \\
\hline & 0.5 & $1.89 \mathrm{Bb}$ & $1.66 \mathrm{Ab}$ & 5.91Aa & 3.15 \\
\hline & 1.0 & $3.55 \mathrm{Bb}$ & $2.52 \mathrm{Ab}$ & $5.62 \mathrm{Aa}$ & 3.90 \\
\hline & 1.5 & $6.40 \mathrm{Aa}$ & $1.65 \mathrm{Ab}$ & $5.50 \mathrm{Ab}$ & 4.52 \\
\hline & 2.0 & 7.58Aa & $1.80 \mathrm{Ac}$ & $4.79 \mathrm{Ab}$ & 4.72 \\
\hline & Average & 4.36 & 1.94 & 4.95 & \\
\hline & C.V. $(\%)$ & 34.43 & & & \\
\hline
\end{tabular}

Note. $\overline{\mathrm{CRH}}=$ carbonized rice husk; $\mathrm{CC}=$ coconut coir; $*$ Means followed by the same uppercase letter in the column and lowercase in the line do not differ from each other by the Tukey Test, at the $5 \%$ error probability level.

Coconut coir presented similar results to those observed for S-10Beifort ${ }^{\circledR}$ and can be used without the addition of other materials. However, the availability and the advantages of using substrates composed of local residues, such as $\mathrm{S}-10 \mathrm{Beifort} \AA$, is beneficial because there is no requirement for carbonization, as is the case for rice husks, allows a reduced labor demand for time consuming activities and also avoids problems of environmental contamination and toxicity due to carbonization smoke. Additionallly, the coconut coir is a substrate of high economical value and of greater difficulty for acquisition in the Southern Region of Brazil. On the other hand, the use of the carbonized rice husk, despite an easy acquisition in this region, did not present favorable results for the development of pansy seedlings.

\section{Conclusion}

The most suitable sowing depths to produce Viola tricolor L. seedlings are 1.5 and $2.0 \mathrm{~cm}$.

Between the substrates evaluated in this study, S10-Beifort ${ }^{\circledR}$ is the most adequate to produce pansy seedlings.

\section{References}

Alves, E. U., Bruno, R. L. A., Alves, A. U., Alves, A. U., Cardoso, E. A., Dornelas, C. S. M., \& Braga Júnior, J. M. (2008). Profundidades de semeadura para emergência de plântulas de juazeiro. Ciência Rural, 38, 1158-1161. https://doi.org/10.1590/S0103-84782008000400042

Alves, M. M., Alves, E. U., Silva-Moura, S. S., Araújo, L. R., Silva, S. R., \& Ursulino, M. M. (2014). Emergência e crescimento inicial de plântulas de Platymiscium floribundum Vog. em função de diferentes posições e profundidades de semeadura. Ciência Rural, 44, 2129-2135. https://doi.org/10.1590/0103-8478 cr20120406

Antunes, L. E. C., Picolotto, L., Vignolo, G. K., \& Gonçalves, M. A. (2012). Influência do substrato, tamanho de sementes e maturação de frutos na formação de muda de pitangueira. Revista Brasileira de Fruticultura, 34, 1216-1223. https://doi.org/10.1590/S0100-29452012000400031

Araújo Neto, S. E., Azevedo, J. M. A., Galvão, R. O., Oliveira, E. B. L., \& Ferreira, R. L. F. (2009). Produção de muda orgânica de pimentão com diferentes substratos. Ciência Rural, 39, 1408-1413. https://doi.org/ $10.1590 / \mathrm{S} 0103-84782009005000099$

Assis, A. M., Unemoto, L. K., Yamamoto, L. Y., Lone, A. B., Souza, G. R. B., Faria, R. T., ... Takahashi, L. S. A. (2011). Cultivo de orquídeas em substratos à base de casca de café. Bragantia, 70, 544-549. https://doi.org/ $10.1590 /$ S0006-87052011000300009 
Brasil, Ministério da Agricultura, Pecuária e abastecimento. (2009). Regras para análise de sementes (p. 389). Mapa/ACS, Brasília, Brazil.

Bullock, C. H., Collier, M. J., \& Convery, F. (2012). Peatlands, their economic value and priorities for their future management-The example of Ireland. Land Use Policy, 29, 921-928.

Cardoso, E. A., Alves, E. U., Bruno, R. L. A., Alves, A. U., \& Silva, K. B. (2008). Emergência de plântula de Erythrina velutina em diferentes posições e profundidades de semeadura. Ciência Rural, 38, 218-2621. https://doi.org/10.1590/S0103-84782008000900034

Caverzan, A., Giacomin, R., Müller, M., Biazus, C., Lângaro, N. C., \& Chavarria, G. (2018). How Does Seed Vigor Affect Soybean Yield Components? Agronomy Journal, 110, 1318-1327. https://doi.org/10.2134/ agronj2017.11.0670

Ceglie, F. G., Bustamante, M. A., Amara, M. B., \& Tittarelli, F. (2015). The challenge of peat substitution in organic seedling production: Optimization of growing media formulation through mixture design and response surface analysis. PLOS ONE, 10, e0128600.

Fernandes, F. S., Leal, T. S., \& Moraes, C. P. (2015). Germinação de sementes de amor-perfeito submetidas a diferentes períodos de exposição e concentrações de GA3. Revista em Agronegócio e Meio Ambiente, 8, 601-614.

Freire, S. E., Alves, U. E., Santos, N. R. S., Porcino, O. G., \& Silva, F. B. (2014). Emergência de plântulas de Bauhinia divaricata L. em diferentes posições e profundidades de semeadura. Bioscience Journal, 30, 774-782.

Junqueira, A. H., \& Peetz, M. S. (2017). Brazilian consumption of flowers and ornamental plants: habits, practices and trends. Ornamental Horticulture, 23, 178-184.

Kämpf, A. N. (2005). Produção comercial de plantas ornamentais (p. 254). Guaíba: Agropecuária.

Kämpf, A. N., De Siqueira, P. T. V., \& Takane, R. J. (2006). Floricultura: Técnicas de preparo de substrates (p. 132). Brasília: LK.

Lone, A. B., Barbosa, C. M., Takahashi, L. S. A., \& Faria, R. T. (2008). Aclimatização de Cattleya (Orchidaceae), em substratos alternativos ao xaxim e ao esfagno. Acta Scientiarum. Agronomy, 30, 465-469. https://doi.org/ 10.4025/actasciagron.v30i4.5299

Lone, A. B., Unemoto, L. K., Yamamoto, L. Y., Costa, L., Schnitzer, J. A., Sato, ... Roberto, S. R. (2010). Enraizamento de estacas de azaleia (Rhododendron simsii Planch.) no outono em AIB e diferentes substratos. Ciência Rural, 40, 1720-1725. https://doi.org/10.1590/S0103-84782010000800008

Maguire, J. D. (1962). Speed of germination-aid selection and evaluation for seedling emergence and vigor. Crop Science, 2, 176-177.

Monquero, P. A., Hijano, N., Orzari, I., Sabbag, R. S., \& Hirata, A. C. S. (2012). Profundidade de semeadura, pH, textura e manejo da cobertura do solo na emergência de plântulas de Rottboellia exaltata. Semina: Ciências Agrárias, 33, 2799-2812.

Nicoloso, F. T., Fortunato, R. P., Zanchetti, F., Cassol, L. F., \& Eisinger, S. M. (2000). Recipientes e substratos na produção de mudas de Maytenus ilicifolia e Apuleia leiocarpa. Ciência Rural, 30, 987-992.

Nomura, E. S., Fuzitani, E. J., Valéria, A. G., Junior, E. R. D., \& Mariotto, G. A. (2011). Aclimatização de mudas de bananeira em substratos contendo resíduo de mineração de areia. Revista Ceres, 58, 481-486. https://doi.org/10.5433/1679-0359.2012v33Supl1p2799

Pádua, G. P., Zito, R. K., Arantes, N. E., \& Neto, J. B. F. (2010). Influência do tamanho da semente na qualidade fisiológica na produtividade da cultura da soja. Revista Brasileira de Sementes, 32, 009-016. https://doi.org/ $10.1590 / \mathrm{S} 0101-31222010000300001$

Sousa, A. H., Ribeiro, M. C. C., Mende, V. H. C., Maracajá, P. B., \& Costa, D. M. (2007). Profundidades e posições de semeadura na emergência e no desenvolvimento de plântulas de moringa. Revista Caatinga, 20, 56-60.

Terra, S. B., Ferreira, A. A. F., Peil, R. M. N., Stumpf, E. R. T., Beckmann-Cavalcante, M. Z., \& Cavalcante, Í. H. L. (2011). Alternative substrates for growth and production of potted Chrysanthemum (cv. Funny). Acta Scientiarum. Agronomy, 33(3), 465-471. https://doi.org/10.4025/actasciagron.v33i3.6991 
Tillmann, M. A. A., Piana, Z., Cavariani, C., \& Minami, K. (1994). Efeito da profundidade de semeadura na emergência de plântulas de tomate (Lycopersicon esculentum Mill.). Scientia Agricola, 51, 260-263.

Xiong, J., Tian, Y., Wang, J., Liu, W., \& Chen, Q. (2017). Comparison of Coconut Coir, Rockwool, and Peat Cultivations for Tomato Production: Nutrient Balance, Plant Growth and Fruit Quality. Frontiers in Plant Science, 8, 1-9. https://doi.org/10.3389/fpls.2017.01327

\section{Copyrights}

Copyright for this article is retained by the author(s), with first publication rights granted to the journal.

This is an open-access article distributed under the terms and conditions of the Creative Commons Attribution license (http://creativecommons.org/licenses/by/4.0/). 